\title{
РАД ЈУГОСЛОВЕНСКИХ СТУДЕНАТА У ФРАНЦУСКОЈ НА ФОРМИРАЊУ И ОЧУВАЊУ КУЛТУРНОГ, НАЦИОНАЛНОГ И ДРЖАВНОГ ИДЕНТИТЕТА ПРЕМА ГЛАСНИКУ ЈУГОСЛОВЕНСКЕ ОМЛАДИНЕ (1918-1919)1
}

\section{Сажетак}

На иницијативу студента историје, Драгољуба Јовановића и студента права, Милоша Милошевића, од новембра 1918. до маја 1919. године, у Паризу је излазио Гласник југословенске омладине, гласило Средишњег одбора југословенских студената у Француској. Часопис је имао велики утицај на очување културног и националног идентитета југословенских студената на школовању у француским универзитетским центрима. Уредништво је промовисало међусобну сарадњу „француских ђака" из свих крајева Краљевине Срба, Хрвата и Словенаца и пружало простор за размену њихових идеја и мишљења.

Кључне речи: културни идентитет, национални идентитет, југословенска нација

\section{Увод}

Почетком 1914. године у француској скупштини покренута је иницијатива да се деци српских бораца погинулих у Балканским ратовима 1912/1913. омогући школовање на француским Лицејима. Током 1915/1916. године, после окупације Србије и повлачења српске војске преко Албаније, са Крфа је кренуо велики број српских омладинаца пут швајцарских, италијанских, грчких, француских и енглеских градова. Образовање српске омладине у Француској у великим униврзитет-

1 Рад је прерађен одломак докторске дисертације Омладинска међуратна периодика - студија и библиографија, одбрањене на Филолошком факултету у Београду 14. 7. 2016. године. 
ским центрима у Паризу, Ници, Поатјеу², Мон Дофену финансирано је средствима француског Министарства просвете и кредитом српске Владе. Поред могућности да се образују и стекну академска звања, „француски ђаци" су имали прилику да упознају француски народ, културу и обичаје. Убрзо по доласку, они оснивају омладинска удружења у жељи да негују и сачувају своју културу и традицију у избеглиштву. Око удружења су се окупљали предузимљиви млади људи који су желели да покрену социјални, економски и културни препород у матици и расејању. Удружења су своју делатност у јавности представљала кроз своја гласила - омладинске часописе.

\section{Улога Гласника југословенске омладине у животу и раду српске односно југословенске омладине у Француској}

Гласник југословенске омладине ${ }^{3}$ био је гласило Средишњег одбора југословенских студената у Француској. Редакција ГЈО се налазила у Rue d'Assas број 118 у Паризу. Цена једног броја била је 0,60 француских франака. Тромесечна претплата је износила 1,5, шестомесечна 3, а годишња 6 франака. Часопис је представљао аутентично сведочанство неисцрпног ентузијазма и родољубља српске односно југословенске омладине у избеглиштву. Главни уредници, изразито пројугословенски и марксистички оријентисани, били су студент историје, Драгољуб Јовановић и студент права, Милош Милошевић. ГЈО се појавио у бурном периоду када је, на рушевинама аустроугарског царства, настајала југословенска држава. Уредништво окупљено око ГЈО координирало је рад свих омладинских удружења у Француској, а касније и осталим европским градовима. Такође, омладина окупљена око редакције пружала је помоћ избеглицама који су сукцесивно пристизале са југословенских простора да се укључе у друштвени живот. Док је Велики рат још трајао, међу српском

2 Већ почетком 1917. године југословенски студенти у француском граду Поатјеу иницирали су сарадњу свих удружења југословенских студената из Француске и Енглеске. Ова иницијатива није дала жељене резултате, јер су студентска удружења била заузета појединачним локалним организационим проблемима. 
омладином негован је „племенски" културни и национални идентитет, а по завршетку интензивно се радило на изградњи ,југословенског духа". Организованим радом кроз омладинска удружења, али и захваљујући појединачној иницијативи и ангажовању, млади Југословени у избеглиштву предано су радили на јачању спољнополитичког положаја југословенске државе. Релативно кратак период излажења, од новембра 1918. до маја 1919. године, не умањује значај прилога који су се појавили на његовим страницама. Прве стране сваког броја биле су резервисане обимније чланке који су представљали критички осврт на актуелна политичка дешавања у свету. Са посебном пажњом југословенска омладина у Француској пратила је политичку ситуацију у Краљевини Срба, Хрвата и Словенаца. Средишње стране ГЈО биле су резервисане за књижевно стваралаштво младих са југословенских простора, али то није био приоритет уредништва. „Њему је био задатак, да се другови међусобно упознају, како би се лакше нашли доцније на заједничком раду, тек потом да даје књижевна дела и студије." ${ }^{4}$ У ГЈО су покренута питања народног просвећивања, оснивања библиотека и читаоница, анализирана улога и слобода штампе, слобода говора и удруживања, критички разматрано будуће унутрашње уређење југословенске државе, као и једнакост у правима и дужностима свих југословенских народа. У великом броју чланака се инсистира на подређивању личног интереса општем, заједничком интересу народа и државе. У 6. броју у чланку „За наш Гласник” уредништво позива претплатнике и добротворе да „сви другови притекну у помоћ”, јер је ГЈО „У рђавим материјалним приликама." Можемо закључити да апел уредништва није дао очекиване резултате, јер се након позива да се прикупе материјална средстава, појавио само још један број ГЈО.

\section{Трагање за националним индентитетом младих са југословенских простора у расејању}

Аустроугарска војна офанзива 1915/1916. године натерала је српску војску, са којом је кренуо читав српски народ, на повлачење

4 Стакић, Владимир. „Гласник југословенске омладине - Париз”. Дан: часопис за литературу и културне проблеме бр. 1-4 (1919): 68. 
преко снегом завејане Албаније. Страдање и жртве српског народа, као и неизвесност повратка у Србију, нису слабили родољубље и веру у победу српске војске. Српски омладинци су на савезничким бродовима напустили Крф и друга острва, али су на све могуће начине покушавали да помогну својој војсци и народу. У тим тренуцима, национална свест била је на високом нивоу. Међутим, како се Велики рат ближио крају, српски омладинци, под утицајем тада актуелних политичких дешавања, постају пројугословенски оријентисани, а сваки хегемонизам, било са српске, хрватске или словеначке стране бива осуђен. „Југословенски национализам није питање територијалног повећања Србије као државе, у ком би случају био империјалистичан, већ је надахнут демократским начелима новог доба тј. да се не оснива ни на каквим хисторијским правима сада или некада постојећих југословенских држава, ни на каквим стратешким или географским обзирима већ на довољно израженој вољи целог југословенског народа." ${ }^{5}$ Југословенска омладина у избеглиштву заузела је јединствен став да се при решавању југословенског питања треба применити начело самоопредељења народа. Сва студентска удружења су осудила сваку врсту неслоге, без обзира да ли су мотиви политичке, верске или личне природе. „Толики идеали нашег народа су на путу да постану стварност: Национално Уједињење, Балканска Федерација, Друштво Народа, и затим, решење Аграрног Питања, употреба општег права гласа, и најзад недалеко од нас, остварење Социјализма. Ни један од ових идеала није у противуречности са другима. Напротив. Један условљава и омогућава други а сви се сливају и налазе свој крајњи облик у остваривању и остварењу Социјализма." 6 У фебруарском броју 1919. године уредништво париског часописа ГЈО јасно и недвосмислено изражава своју левичарску оријентацију. Док за Хрвате улазак у Краљевину СХС представља први корак ка стицању независности, за марксистички оријентисане омладинце то је само прелазни облик до социјалистичке државе. „Време захтева не само да нема више круна, већ да и краљеви богатства ишчезну! Време

5 Iveša, M. „Naš pokret” Glasnik Jugoslovenske omladine br. 1 (1918): 4.

6 Jovanović, D. „Ličnim Naporom za Opšte Dobro”. Glasnik jugoslovenske omladine br. 4 (1919): 50 . 
тражи праву слободу радничких и сеоских маса. Време тражи да југословенска заједница буде: Социјалистичка организација рада!"7 Вишевековна борба за слободу српског народа јачала је колективну националну свест и усадила му љубав према слободи и правди. Велико сиромаштво владало је у српским областима које су ушле у састав Краљевине СХC, па су социјалистичке идеје о друштвеној једнакости и социјалној правди наилазиле присталице, нарочито, међу радничком омладином.

Оснивањем Краљевине Срба, Хрвата и Словенаца ${ }^{8}$ 1. децембра 1918. године у истој држави нашли су се народи који су вековима живели у различитим друштвеним, културним, политичким и економским условима, па је било неопходно промовисати идеју „интегралног југословенства” и радити на изградњи јединственог духа југословенске нације, како би новооснована држава стекла политичку и економску стабилност. „Југословени су до данас живели у три или четири разне државе, у шест државноправних тела и не знам колико управних области. Та подвојеност је морала оставити својих трагова у менталитету појединих делова нашег народа. У свакој покрајини се живело другим животом, под различитом управом, у повољнијим или горим материјалним условима за живот, у мање или више развијеној народној образованости. Поменућу разлику у вери, која неоспорно много, врло много утиче на начин живота, на његово схватање на одгој." у жељи да створе „јединствени југословенски дух", правдане су разликама у вери и културном и економском развоју области које су ушле у састав нове државе. Поражавајућа је заслепљеност и наивност српске омладине вером да су сви конститутивни народи искрене присталице југословенске идеје. „Француски ђаци” који су у међуратном периоду постали део југословенске интелектуалне елите 1918. године не увиђају постојање различитих националних интереса са којима државотворни народи улазе у Краљевину СХС. Српски

7 Stevanović, R. „Pravo Narodno Jedinstvo” Glasnik Jugoslovenske omladine br. 4 (1919): 53.

8 У њен састав су ушле Краљевина Србија, Краљевина Црна Гора, као и територије које су се пре Великог рата налазиле у саставу Аустро-Угарске царевине: Босна и Херцеговина, Хрватска са Славонијом и Далмацијом, Словенија и Војводина. Iveša, M. „Federalizam i centralizacija”. Glasnik jugoslovenske omladine br. 6 (1919): 82. 
омладинци који су у земље Западне Европе стигли као Срби преко ноћи су постали најватреније присталице југословенске идеологије и уједињења свих југословенских народа у једну државу.

У бурном времену по окончању Првог светског рата, када је судбина заједничке државе Јужних Словена била у рукама великих сила, подршка пројугословенски оријентисаног уредништва ГЈО била је драгоцена. „По свим варошима Француске и Енглеске студенти су обавештавали страно јавно мњење предавањима и сарадњом са месним новинама о значењу југословенског питања и о његовом правом месту у склопу међународних проблема." ${ }^{10}$ Поред културних, спортских и образовних активности, студенти са југословенских простора су се борили, у оквиру својих могућности, да представе ставове и мишљења југословенских народа моћним савезницима који одлучују о судбини будуће заједничке државе.

На насловној страни првог број ГЈО који се појавио месец дана пре оснивања Краљевине СХС, Средишњи одбор југословенских студената у Паризу издао је проглас у коме позива омладину са југословенскеих простора да уједини своје снаге у изградњи заједничке домовине. Уредништво Гласника југословенске омладине истиче да ће часопис бити „слободна говорница” којој ће приступ имати само пројугословенски оријентисани говорници. „У листу ће се пуштати сва гледишта начелно и посебно изложена. Постоје само два ограничења. Она су очигледна, али их је ипак потребно подвући, да би се избегли сви неспоразуми. Уредништво стоји на гледишту народног ослобођења и уједињења. Оно сматра да је уједињење југословенског народа у једну независну државу нешто неприкосновено и свето, што не сме да се ставља у питање. Зато ће све што се буде ма издалека косило са овим схватањем бити најодлучније одбачено. Друго ограничење је народно јединство. Уредништво неће пустити у лист ни једно гледиште у коме би се огледала покрајинска нетрпељивост, тражила народна поцепаност или тежило превласти једног дела народног над осталима" ${ }^{11}$. Од првог до последњег броја уредништво ГЈО је остало доследно наведеним принципима.

10 Iveša, M. „Naš pokret” Glasnik Jugoslovenske omladine br. 1 (1918): 5.

11 „Od uredništva”. Glasnik Jugoslovenske omladine br. 1, (1918): 15. 
Поред политичке, југословенска омладина у избеглиштву била је свесна неопходности економског напретка новоосноване државе. Пре Првог светског рата југословенска омладина је живела у више држава, па није имала могућности да интензивније сарађује. „Крвави догађаји су их (југословенске омладинце) разбацали на све стране: једне су утопили у реци смрти, друге отерали са њиховог родног земљишта, а све их осудили на физичке и моралне патње без краја"12. Стицајем различитих околности један део омладинаца са југословенских простора је остао у земљи, други је емигрирао, трећи је страдао у рату, а четврти је провео рат у заробљеништву. Саосећајући са патњама свога народа, студенти у Француској су покушавали да помогну на разне начине. Док је Велики рат још трајао, они су прикупили и послали ратним заробљеницима пакете са храном у вредности око 120000 француских франака. „И хитамо да вас уверима све да ваши другови на страни имају само једну жељу доћи у везу са свима вама, учинити све што би требало да и ви постигнете у наукама оно што смо ми постигли". ${ }^{13}$ Стекавши образовање у престижним универзитетским центрима, „француски ђаци” су увидели да напредак новоосноване југословенске државе умногоме зависи од образовања омладине. Својим угледом и везама настоје да помогну својим сународницима који нису били у прилици да се школују. „Ми смо, у великим европским земљама, много видели, много научили, много осетили. Призори величине и лепоте којима се хранимо већ скоро три године населили су наше душе за увек. Француска, Енглеска, Италија! Шта смо све преживели! Један по један, као што смо прилазили тим величинама, ми ћемо их оставити, поносећи са собом њихову слику. Ићи ћемо нашој земљи коју неизмерно волимо и желимо. Обогаћени и одушевљени вредностима на које смо овде навикли, ми ћемо у домовини извести многе велике ствари. На нама је да уредимо и улепшамо наше вароши и села, да проширимо путеве, да умножимо железнице и друга саобраћајна средства. Ми дугујемо нашем народу сва она блага са којима смо се упознали у изгнанству и којима смо се

12 „Jugoslovenska omladina i događaji : Proglas Središnog Odbora”. Glasnik jugoslovenske omladine br. 1 (1918): 1.

13 „Jugoslovenska omladina i događaji : Proglas Središnog Odbora”. Glasnik jugoslovenske omladine br. 1 (1918): 1. 
сами користили. Ми му исто тако дугујемо оне широке слободе које допуштају свестрано развијање и које чине достојанство једног народа." ${ }^{14}$ По завршетку школовања већина академски образованих младих људи вратила се у своју ратом разорену и економски неразвијену домовину у жељи да својом стручношћу и знањем допринесе њеном економском и културном напретку.

\section{Закључак}

Гласник југословенске омладине је у потпуности остварио своју мисију - да југословенској омладини у Француској пружи простор и прилику да изнесе своје мишљење, идеје, проблеме и ставове. Поред тешке материјалне ситуације, одређени број примерака ГЈО уредништво је слало омладини у матици, и на тај начин остваривало сарадњу и доприносило размени мишљења и упознавању младих у земљи и расејању. Својим преданим радом уредници и сарадници часописа дали су изузетан допринос јачању југословенско-француске културне сарадње.

\section{Литература}

Iveša, M. „Naš pokret” Glasnik Jugoslovenske omladine br. 1 (1918): 4-5.

Iveša, M. „Federalizam i centralizacija”. Glasnik jugoslovenske omladine br. 6 (1919): 82-84. Jovanović, Dragoljub. „Ličnim Naporom za Opšte Dobro”. Glasnik jugoslovenske omladine br. 4 (1919): 50.

Jovanović, Dragoljub. „Udruživanje radi stvaranja”. Glasnik jugoslovenske omladine br. 1 (1918): 2-3.

„Jugoslovenska omladina i događaji : Proglas Središnog Odbora”. Glasnik jugoslovenske omladine br. 1 (1918): 1.

„Od uredništva”. Glasnik Jugoslovenske omladine br. 1, (1918): 15.

Стакић, Владимир. „Гласник југословенске омладине - Париз”. Дан : часопис за литературу и културне проблеме бр. 1-4 (1919): 67-68.

Stevanović, R. „Pravo Narodno Jedinstvo” Glasnik Jugoslovenske omladine br. 4 (1919): 52-53.

14 Jovanović, Dragoljub. „Udruživanje radi stvaranja”. Glasnik jugoslovenske omladine br. 1 (1918): 2. 
Radmila N. Tasić

\title{
THE WORK OF YUGOSLAV STUDENTS IN FRANCE \\ ON THE FORMATION AND PRESERVATION \\ OF CULTURAL, NATIONAL AND STATE IDENTITY ACCORDING TO THE \\ GLASNIK JUGOSLOVENSKE OMLADINE (1918-1919)
}

\begin{abstract}
Summary
On the initiative of the student of history, Dragoljub Jovanović and law student, Miloš Milošević, from November 1918 to May 1919, in Paris, Glasnik jugoslovenske omladine, a newsletter of the Central Committee of Yugoslavian students in France, was published monthly. The magazine had a great influence on the preservation of the cultural and national identity of Yugoslav students in education at the French university centers. The editorial office promoted the mutual cooperation of "French pupils" from all parts of the Kingdom of Serbs, Croats and Slovenes and provided space for exchange of their ideas and opinions.
\end{abstract}

Key words: Cultural identity, national identity, Yugoslav nation 